Int. J. Morphol.,

39(3):780-784, 2021.

\title{
Crown Formation Times of Deciduous Teeth and Age at Death in Neolithic Newborns
}

\author{
Tiempos de Formación de la Corona de los Dientes \\ Deciduos y Edad al Morir en Neonatos Neolíticos
}

Milica Sipovac ${ }^{1,2}$; Bojan Petrovic ${ }^{1}$; Sanja Kojic ${ }^{3}$; Jelena Pantelinac'; Kristina Penezic ${ }^{4}$; Ivan Capo \& Sofija Stefanovic $^{2,4}$

SIPOVAC, M.; PETROVIC, B.; KOJIC, S.; PANTElinAC, J.; PENEZIC, K.; CAPO, I. \& STEFANOVIC, S. Crown formation

times of deciduous teeth and age at death in Neolithic newborns. Int. J. Morphol., 39(3):780-784, 2021.

SUMMARY: The aim of the present study was to investigate the possibility of estimating crown formation times of immature deciduous teeth and age at death in Neolithic newborns. In the Neolithic-Mesolithic transition, the health of the population deteriorated. Leaving the intrauterine environment for the newborn is the first obstacle in the process of adaptation and survival in the outside world. The fetus is protected by the mother's immune system and receives the necessary nutrients through the umbilical cord, but external factors indirectly affect its development. At birth deciduous teeth are not fully formed and are only partially mineralized. Variations in the rhythmic activity of ameloblasts and the secretion of the enamel matrix lead to the formation of incremental lines in the enamel. The sample consisted of unerupted deciduous teeth removed from the baby jaws from Neolithic archaeological graves, LepenskiVir Serbia. The skeletal age of the babies was from 38 to 40 gestational weeks. The daily enamel apposition rate was obtained for each tooth. The age of individuals was estimated using crown formation time. The average value of daily secretion rates for the primary teeth from the Neolithic age was $3.78 \mu \mathrm{m}$. There was no statistically significant difference in age at death determined by skeletal age assessment and crown formation time. Three babies were born preterm. The results of the present study show that the calculation of the time required for the formation of deciduous tooth enamel is applicable to archaeological samples of newborns. The age estimation using crown formation time together with the analysis of other anthropological parameters, can contribute to a more accurate determination of neonatal death in anthropological, archaeological and forensic contexts.

KEY WORDS: Deciduous teeth; Dental enamel; Age estimation; Incremental lines.

\section{INTRODUCTION}

The early Neolithic period is characterized by the transition from a nomadic (hunter-gatherer) way of life to a life in organized communities, the beginning of agriculture, and the gradual use of secondary products (Marciniak, 2011). This period is known as the Neolithic demographic transition due to numerous lifestyle changes that led to social changes, increasing fertility, and mortality rates (Bocquet-Appel, 2002). Malnutrition, the consequent decline in human health, and exposure to sources of infection have often had fatal consequences for the most vulnerable social groups, infants, young children, and the elderly (Armelagos et al., 1991). The high prevalence of buried infants whose age is estimated at 38-40 gestational weeks may indicate infanticide especially if one sex dominates the sample (Mays, 1999). Children, up to the age of five, represent the most vulnerable part of society and their health condition affects the overall ability of the population to be resistant to certain diseases (Goodman \& Armelagos, 1989).

At birth, deciduous teeth are not fully formed and they are only partially mineralized (Sabel et al., 2008). Variations in the rhythmic activity of ameloblasts and the secretion of the enamel matrix lead to the formation of incremental lines in the enamel: cross striations, striae of Retzius, and neonatal line (Asper, 1916; Risnes, 1986).

\footnotetext{
${ }^{1}$ University of Novi Sad, Faculty of Medicine Novi Sad, Department of Dentistry, HajdukVeljkova 3, 21000 Novi Sad, Republic of Serbia.

${ }^{2}$ University of Belgrade, Faculty of Philosophy, CikaLjubina 18-20, 11000 Belgrade, Republic of Serbia.

${ }^{3}$ University of Novi Sad Faculty of Technical Sciences Novi Sad, Trg Dositeja Obradovica 6, Republic of Serbia

${ }^{4}$ University of Novi Sad, BiosenseInstitut, Novi Sad,DrZoranaDjindjica 1, Republic of Serbia.

${ }^{5}$ University of Novi Sad, Faculty of Medicine Novi Sad, HajdukVeljkova 3, 21000 Novi Sad, Republic of Serbia.

This work was supported by H2020 ERC project BIRTH No. 640557 and Serbian national project III 47001.
} 
Cross striations represent the activity of ameloblasts during $24 \mathrm{~h}$ (Asper; Risnes) and they are located orthogonally to enamel prisms at a uniform distance of $4 \mu \mathrm{m}$ from each other (Maji, 2008). The distance between cross striations represents the daily rate of ameloblastic secretion - daily secretion rate (DSR) (Risnes).

The estimation of age at the time of death is in most cases based on the length of the diaphysis of long bones, which leads to a rough estimate of age and excludes the possibility of distinguishing preterm from term births (Boric' $\&$ Stefanovic, 2004).

The aim of this paper was to investigate the possibility of estimating crown formation times of immature deciduous teeth and age at death in Neolithic newborns.

\section{MATERIAL AND METHOD}

The sample consisted of 30 unerupted deciduous teeth removed from the baby jaws from Neolithic archaeological graves, LepenskiVir Serbia. LepenskiVir is an archaeological site that is significant for its numerous and the richest dataset study of the Mesolithic-Neolithic transition in Southeast Europe (Boric, 1999). The skeletal age of the babies was determined (38-40 gestational weeks), but unknown for the researchers who were analyzing teeth sections. The skeletal remains from this archaeological site date from $6200 \mathrm{BC}$ to 5950 BC. Only 11 deciduous teeth ( $(\mathrm{di} 1=9), \mathrm{n}(\mathrm{dm} 1=2)$ entered further investigation due to the visible microstructures necessary for analysis.

Sectioning and preparation of samples. The Neolithic deciduous teeth were fragile, and they were embedded in Biodur epoxy resin. They were histologically sectioned along the central labio-lingual plane by Isomet 1000, Buehler. Prepared sections had final thickness of $80-100 \mu \mathrm{m}$. The speed of blade rotation was set at 140 RPMs.

Microscoping. The neonatal line visibility and width, prenatal and postnatal enamel structure were analyzed on each slice under a polarization microscope Leica DMLB 100T (Leica Microsystems $\mathrm{GmbH}$ ) at $\times 10$ - ×400 magnifications. Images were captured using a Leica MC190 HD camera (Leica Microsystems GmbH). Samples were photographed under 10×, 20×, and 40× magnification. Slices with the visible prenatal, postnatal enamel, neonatal line and Retzius striae, accentuated lines were chosen for further research. Cross striations were analyzed at $40 \times$ magnification. In each third of the deciduous tooth, 20 random measurements were made between 6 cross striations. Based on these values, the

daily enamel apposition rate was obtained for each tooth (Birch \& Dean, 2009).

Estimation the age at death. The age of individuals was estimated using crown formation time (CFT). For calculating crown formation time (CFT) we followed Risnes and Dean (2012). As shown in Figure 1, photomontages were made in Adobe Photoshop (Adobe Inc) from photographs showing segments of the labial surface of the deciduous tooth. The direction of the first Retzius line to the dentine horn was used as a landmark for ameloblast pathway measurement during crown formation in the incisal-cervical direction (Risnes). Avoiding the area of gnarled enamel the line was followed back to the enamel-dentin junction. Each section was measured four times by two clinicians and the mean value was calculated. The influence of the deviation of the enamel prisms from the perpendicular direction of $30^{\circ}, 15$ ${ }^{\circ}$ at the lateral aspects on the ameloblast length was considered (Risnes). The crown formation time in the Neolithic deciduous teeth was estimated by dividing complete distance traveled by ameloblasts in incisal-cervical direction with the average value of the DSR (Dean). The number of weeks in which the mineralization of deciduous incisors and molars in-utero begins (16-20 weeks) (Lunt \& Law, 1974) was added to the calculated value of the time of crown formation. This value represented the time when the mineralization stopped - in this case the age at death.

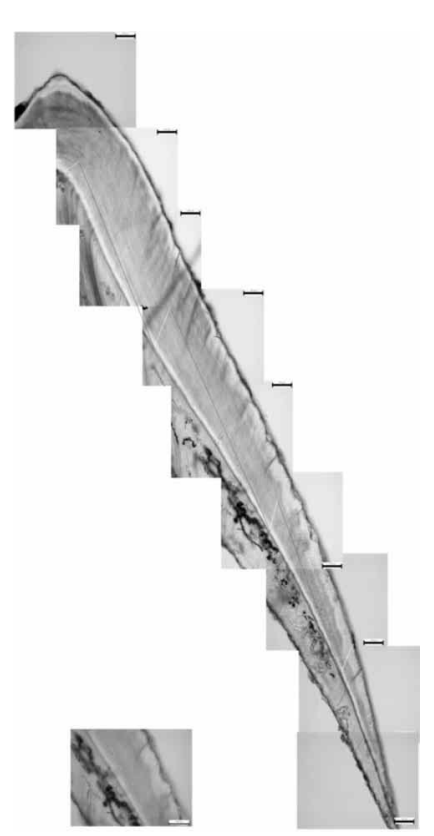

Fig. 1. Photomontage of the deciduous tooth from the Neolithic age.Accentuated lines as landmarks for estimating the crown formation time. 
RESULTS

The average value of daily secretion rates (DSR) for the deciduous teeth from the Neolithic age was $3.78 \mu \mathrm{m}$ (Table I). There was no significant differences between DSR in different thirds of the tooth crowns ( $p>0.05)$.

Based on the $\mathrm{t}$-test $(\mathrm{t}=0.112), 40$ weeks was the most approximate value of the estimated skeletal age of newborns from LepenskiVir.

Figure 2 shows the crown formation time for the 11 teeth in the Neolithic sample and the time at which the break in development occurred. There were no significant differences between the CFT calculated on measured values of the complete length traveled by ameloblasts and the values modified by deviation of the enamel prisms from the perpendicular direction of $30^{\circ}$ and $15^{\circ}(\mathrm{p}>0.05)$. There was no statistically significant difference in the estimated age at death determined by the diaphyseal length of the long bones and age at death determined by the CFT( $p>0.05)$. According to estimated age at death, 3 preterm newborns died immediately after birth: M3 (34.97 gestational weeks), M5 (35.86 gestational weeks), M23 (35.53 gestational weeks).

Table I. Daily secretion rates (DSR) in $\mathrm{mm} /$ day.

\begin{tabular}{lccccc}
\hline Individual & Tooth & DSR CERVICAL $\mu \mathrm{m}$ & DSR MEDI AL $\mu \mathrm{m}$ & DSR INCISAL $\mu \mathrm{m}$ & As DSR $\mu \mathrm{m}$ \\
\hline M1 & 82 & 3.74 & 4.33 & 4.87 & 4.31 \\
M1 & 71 & 3.82 & 4.21 & 3.65 & 3.89 \\
M22 & 51 & 4.57 & 5.43 & 4.09 & 4.69 \\
M15 & 84 & 3.44 & 3.46 & 2.75 & 3.21 \\
M4 & 82 & 2.72 & 3.37 & 3.12 & 3.07 \\
M3 & 81 & 3.00 & 3.03 & 2.99 & 3.00 \\
M6 & 81 & 2.82 & 3.13 & 2.71 & 2.88 \\
M16 & 72 & 3.38 & 3.45 & 3.08 & 3.30 \\
M5 & 52 & 4.57 & 5.44 & 4.09 & 4.70 \\
M1 & 61 & 4.48 & 5.29 & 3.74 & 4.50 \\
M23 & 84 & 3.62 & 4.45 & 3.83 & 3.96 \\
\hline
\end{tabular}

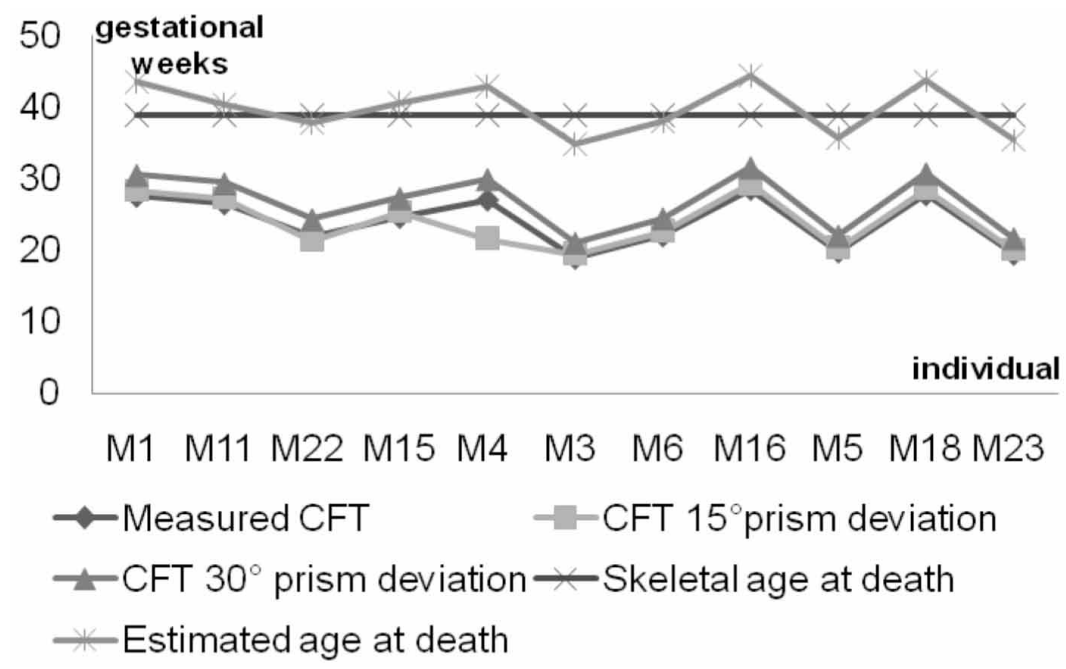

Fig. 2. Crown formation time (CFT), skeletal age at death, and estimated age at death in weeks in the group of primary teeth from the Neolithic age. $\mathrm{M}$ - archaeological individuals from LepenskiVir. 


\section{DISCUSSION}

In paleodemography, age estimation is based on analyzes of skeletal growth, skeletal development, and dental development (Ubelaker, 1987). Investigating the prenatal and perinatal life of prehistoric babies is important to determine life expectancy, identify causes of death, mortuary praxis, and obtain data comparable to the results of other archaeological studies.

Asper was the first who noticed the appearance of cross-striations while analyzing Retzius lines on specimens of maxillary permanent canines. Enamel and dentin have rhythmic growth and it is possible to measure the periodicity of the formation of incremental lines (Risnes.; Dean). The distance between dark and bright lines with a perpendicular orientation to the longitudinal axis of the enamel prism represents a daily linear increase in enamel width. Schour \& Poncher (1937) claim that the average daily secretion rate of enamel formation is $3.92 \mu \mathrm{m}$, and of dentine is $3.77 \mu \mathrm{m}$. The prenatal DSR values of neonates from the Velia region ranged from $2.7 \mu \mathrm{m}$ to $5.8 \mu \mathrm{m}$ (Nava et al., 2017) and were statistically significantly different from the DSR in a sample of modern teeth (Birch, 2011). The DSR range of LepenskiVi rsample $(2.71 \mu \mathrm{m}$ to 5.44 $\mu \mathrm{m})$ fits with the the DSR range of the Velia sample reported in Nava et al. Risnes noticed that the width of the cross striations was not equal in all parts of the tooth. The differences are particularly pronounced in the incisal third and in the lateral aspects of the tooth due to the presence of an irregular structure of the enamel and the appearance of an optical phenomenon resulting from the intersection of prisms (Risnes). The authors investigated the periodicity of cross striations and daily secretion rates on permanent dental samples (Asper; Risnes; Dean). However, the analysis of the deciduous teeth enamel in which development is not completed is challenging. It is difficult to observe an uniform arrangement of cross striations, especially in the area of the dentin-enamel junction where the enamel has a largely a prizmatic structure (Dean; Nava et al.). Absence of cross striations and neonatal line excluded 19 individuals from this study. However the visible cross striations in other 11 newborns provided obtaining an average DSR value, which allowed the estimation of crown formation time, and the time when the break in enamel formation occurred.

Age estimation of immature human skeletal remains from the diaphyseal length of the long bones is a widespread method. However, it is not entirely acceptable and accurate as it is designed to determine average length of the long bones to assess growth status in live children
(Cardoso et al., 2014). Humphrey (2000) investigated the growth of long bones of children from different socioeconomic environments. Growth and development rates are significantly lower in children from developing countries who are exposed to malnutrition and infectious agents than those in developed western countries. Cardoso et al. proposes abandoning the inverse calibration method and cites unreliability as one of the main drawbacks. Although measuring the diaphyseal length of the long bone is considered a good alternative for estimating the age of children's skeletons based on immature dental structures (Cunha et al., 2009), it leads to an approximate time of death that can range from a few weeks.

Boric \& Stefanovic investigated the graves of newborns located under the floors of houses in LepenskiVir. Based on skeletal age, they were born after the $37^{\text {th }}$ gestational week. However, CFT and beginning of the mineralization point that there are still premature babies in the sample. Preterm babies with immature lungs are prone to respiratory infections, acute respiratory distress syndrome (ARDS), neurological diseases and sudden death (Kramer et al., 2000). The relationship between endogenous and exogenous factors, which have influenced child mortality in the past, can be observed through the number of babies who died by the $40^{\text {th }}$ week of gestation (Lewis, 2002). Boric \& Stefanovic reject the possibility of infanticide according to funeral practices and burying babies with their mothers, but recognizes the presence of cribra orbitalia as an indicator of poor health status. Nava et al. described the CFT of the deciduous incisors in the prenatal period. Compared to other deciduous teeth, the enamel of deciduous incisors is almost completely formed prenatally (Mahoney, 2015). In the present investigation CFT of deciduous incisors in the prenatal and postnatal period is approximate to the values of prenatal CFT obtained by direct counting or a new regression method (Nava et al.).

The results of the present study show that the calculation of the time required for the formation of deciduous tooth enamel is applicable to archaeological samples of newborns. There are no statistically significant differences in the time required for the formation of deciduous tooth enamel in relation to the localization. The age estimation using crown formation time together with the analysis of other anthropological parameters, can contribute to a more accurate determination of neonatal death in anthropological, archaeological and forensic contexts. 
SIPOVAC, M.; PETROVIC, B.; KOJIC, S.; PANTELINAC, J.; PENEZIC, K.; CAPO, I. \& STEFANOVIC, S. Tiempos de formación de la corona de los dientes deciduos y edad al morir en neonatos neolíticos. Int. J. Morphol., 39(3):780-784, 2021.

RESUMEN: El objetivo del estudio fue investigar la posibilidad de estimar el tiempo de formación de la corona de los dientes deciduos inmaduros y la edad, al momento de la muerte en neonatos neolíticos. Durante la transición Neolítico-Mesolítico, la salud de la población deterioró significativamente. Para el recién nacido dejar el medio intrauterino es el primer obstáculo en el proceso de adaptación y supervivencia en el mundo exterior. El feto está protegido por el sistema inmunológico de la madre y recibe los nutrientes necesarios a través del cordón umbilical, pero factores externos afectan indirectamente su desarrollo. Al nacer, los dientes deciduos no están completamente formados y solo están parcialmente mineralizados. Las variaciones en la actividad rítmica de los ameloblastos y la secreción de la matriz del esmalte conducen a la formación de líneas incrementales en el esmalte. La muestra consistió en dientes sin erupción extraídos de las mandíbulas de neonatos de tumbas arqueológicas neolíticas, LepenskiVir Serbia. La edad esquelética de los bebés fue de 38 a 40 semanas de gestación. Se obtuvo la tasa diaria de aposición de esmalte para cada diente. La edad de los individuos se estimó utilizando el tiempo de formación de la copa. El valor promedio de las tasas de secreción diaria para los dientes temporales del Neolítico fue de 3,78 $\mu \mathrm{m}$. No hubo diferencia estadísticamente significativa en la edad al momento de la muerte determinada por la evaluación de la edad esquelética y el tiempo de formación de la corona. Tres bebés nacieron prematuros. Los resultados del presente estudio muestran que el cálculo del tiempo requerido para la formación del esmalte dental deciduo es aplicable a muestras arqueológicas de recién nacidos. La estimación de la edad utilizando el tiempo de formación de la corona junto con el análisis de otros parámetros antropológicos, puede contribuir a una mayor determinación precisa de la muerte neonatal en contextos antropológicos, arqueológicos y forenses.

PALABRAS CLAVE: Dientes deciduos; Esmalte dental; Estimación de la edad, Líneas incrementales.

\section{REFERENCES}

Armelagos, G. J.; Goodman, A. H. \& Jacobs, K. H. The origins of agriculture: Population growth during a period of declining health. Popul. Environ., 13(1):9-22, 1991.

Asper, H. Uber die 'Braune Retzius'sche Parallelstreifung' im Schmelz der Menschlichen Zähne. Schweiz. Vischr. Zhk., 26:275, 1916.

Birch, W. \& Dean, C. Rates of Enamel Formation in Human Deciduous Teeth. In: Koppe, T.; Meyer, G. \& Alt, K. W. (Eds.). Comparative Dental Morphology. New York, Karger, 2009. pp.116-20.

Birch, W. Incremental Growth of Deciduous Tooth Enamel. PhD Thesis. London, University College London, 2011.

Bocquet-Appel, J. P. Paleoanthropological traces of a Neolithic demographic transition. Curr. Anthropol., 43(4):637-50, 2002.

Boric, D. \& Stefanovic, S. Birth and death: infant burials from Vlasac and Lepenski Vir. Antiquity, 78(301):526-46, 2004.

Boric, D. Places that created time in the Danube Gorges and beyond, c. 90005500 BC. Doc. Praehist., 26:41-70, 1999.

Cardoso, H. F. V.; Abrantes, J. \& Humphrey, L. T. Age estimation of immature human skeletal remains from the diaphyseal length of the long bones in the postnatal period. Int. J. Legal Med., 128(5):809-24, 2014.

Cunha, E.; Baccino, E.; Martrille, L.; Ramsthaler, F.; Prieto, J.; Schuliar, Y.; Lynnerup, N. \& Cattaneo, C. The problem of aging human remains and living individuals: a review. Forensic Sci. Int., 193(1-3):1-13, 2009.

Dean, M. C. A Histological Method that Can Be Used to Estimate the Time Taken to Form the Crown of a Permanent Tooth. In: Bell, L. S. (Ed.). Forensic Microscopy for Skeletal Tissues. Methods and Protocols. Totowa (N. J.), Humana Press, 2012. pp.89-100.

Goodman, A. H. \& Armelagos, G. J. Infant and childhood morbidity and mortality risks in archaeological populations. World Archaeol., 21(2):22543, 1989.

Humphrey, L. Growth studies of past populations: an overview and an example. Hum. Osteol. Archaeol. Forensic Sci., 23-38, 2000.

Kramer, M. S.; Demissie, K.; Yang, H.; Platt, R. W.; Sauvé, R. \& Liston, R. The contribution of mild and moderate preterm birth to infant mortality. Fetal and Infant Health Study Group of the Canadian Perinatal Surveillance System. JAMA, 284(7):843-9, 2000.

Lewis, M. E. Urbanisation and Child Health in Medieval and Post-Medieval England. Oxford, Archaeo Press, 2002.

Lunt, R. C. \& Law, D. B. A review of the chronology of calcification of deciduous teeth. J. Am. Dent. Assoc., 89(3):599-606, 1974.

Mahoney, P. Dental fast track: prenatal enamel growth, incisor eruption, and weaning in human infants. Am. J. Phys. Anthropol., 156(3):407-21, 2015.

Maji, J. Essentials of Oral Biology: Oral Anatomy, Histology, Physiology \& Enbryology. New Delhi, CBS Publishers \& Distributors, 2008.

Marciniak, A. The secondary products revolution: empirical evidence and its current zooarchaeological critique. J. World Prehist., 24(2-3):11730, 2011.

Mays, S. The Archaeology of Human Bones. New York, Routledge, 1999.

Nava, A.; Bondioli, L.; Coppa, A.; Dean, C.; Rossi, P. F. \& Zanolli, C. New regression formula to estimate the prenatal crown formation time of human deciduous central incisors derived from a Roman Imperial sample (Velia, Salerno, Italy, I-II cent. CE). PLoS One, 12(7):e0180104, 2017.

Risnes, S. Enamel apposition rate and the prism periodicity in human teeth. Scand. J. Dent. Res., 94(5):394-404, 1986.

Sabel, N.; Johansson, C.; Kühnisch, J.; Robertson, A.; Steiniger, F.; Norén, J. G.; Klingberg, G. \& Nietzsche, S. Neonatal lines in the enamel of primary teeth--a morphological and scanning electron microscopic investigation. Arch. Oral Biol., 53(10):954-63, 2008.

Schour, I. \& Poncher, H. G. Rate of apposition of enamel and dentin, measured by the effect of acute fluorosis. Am. J. Dis. Child., 54(4):757-76, 1937.

Ubelaker, D. H. Estimating age at death from immature human skeletons: an overview. J. Forensic Sci., 32(5):1254-63, 1987.

\section{Corresponding author: \\ MilicaSipovac \\ University of Novi Sad \\ Faculty of Medicine Novi Sad \\ Department of Dentistry \\ HajdukVeljkova 3 \\ 21000 Novi Sad \\ REPUBLIC OF SERBIA}

E-mail: mnsipovac@gmail.com 